\title{
Biochemical evaluation of dent corn (Zea mays L.) genotypes cultivated under rainfed conditions in the hills of north western Indian Himalayan state of Jammu and Kashmir
}

\author{
Sheikh Mohammad Sultan ${ }^{1 *}$, Nilamani Dikshit ${ }^{2}$, Chandra Sekhar Mohanty ${ }^{3}$, Prasant \\ Kumar Rout $^{4}$ and Susheel Kumar Raina ${ }^{1}$ \\ ${ }^{1}$ ICAR-National Bureau of Plant Genetic Resources, Regional Station, Srinagar-190007 (J \& K), INDIA \\ ${ }^{2}$ ICAR-National Bureau of Plant Genetic Resources, Regional Station, Akola-444104 (Maharashtra), INDIA \\ ${ }^{3}$ CSIR-National Botanical Institute, Lucknow-226001 (Uttar Pradesh), INDIA \\ ${ }^{4}$ CSIR-Central Institute of Medicinal and Aromatic Plants, Lucknow-226001 (Uttar Pradesh), INDIA \\ *Corresponding author. E-Mail: sheikhmsultan@gmail.com \\ Received: August 1, 2017; Revised received: September 5, 2017; Accepted: January 25, 2018
}

\begin{abstract}
The aim of present study was to investigate protein, oil and fatty acid composition in 11 maize (Zea mays) genotypes collected from diverse locations in the hills of north western Indian Himalayan state of Jammu and Kashmir in order to get an idea about the extent of variability in these biochemical traits in the local germplasm. The study revealed significant variation in these quality traits. The protein content among the genotypes ranged from $10.7 \%$ to $18.7 \%$ while oil content varied between $2.26 \%$ and $4.80 \%$. Higher protein content in some of the genotypes especially IC-0617877 (18.7\%) and IC-0617880 (17.6\%) is noteworthy. The saturated fatty acids of palmitic (C16:0), stearic (C18:0), arachidic (C20:0) and unsaturated fatty acids of oleic (C18:1), linoleic (C18:1) and elaidic (C18:1) were detected and quantified in these genotypes. Considerable variation has been recorded in fatty acid composition; $13.8-33.4 \%$ for palmitic acid, $21.5-48.1 \%$ for linoleic acid, $19.2-39 \%$ for oleic acid, $0.2-2.4 \%$ for elaidic acid, $2.5-$ $8.5 \%$ for stearic acid and $0.1-6.6 \%$ for arachidic acid. Higher oleic acid content recorded in all the genotypes excepting IC-0617881 is a useful trait. Strikingly, highest oil $(4.80 \%)$, palmitic acid $(33.4 \%)$, stearic acid (8.5\%) and arachidic acid $(6.6 \%)$ contents have been recorded in this remarkably cold tolerant genotype with reddish yellow seeds containing moderate protein content of $13.8 \%$. The appreciable variation in these quality traits could be exploited in breeding programmes for improvement of this crop and opening up new opportunities for its food and industrial end uses.
\end{abstract}

Keywords: Fatty acids, Genotypes, Oil content, Protein content, Zea mays L.

\section{INTRODUCTION}

Maize (Zea mays L.) belonging to the family Poaceae, is the third largest cereal crop after wheat and rice cultivated worldwide and used as food, feed and as raw material for various industrial applications like production of starch, beverages, glue, industrial alcohol and fuel alcohol. Domestication of maize is believed to have taken place some nine thousand years ago in the Balsas River region in western Mexico from tropical teosinte, Zea mays ssp. parviglumis (Matsuoka et al., 2002, Doebley, 2004). Mexico has the highest diversity of maize germplasm (Ortega, 2000). The ultimate expression of maize domestication and subsequent diffusion was its diversification into numerous landraces, each of which has acquired distinct genetic and morphological characteristics mainly due to local adaptation and human selection (Vigouroux et al., 2008). It is now a key source of food and livelihood for mil- lions of people in many countries of the world (Enujeke, 2013). Corn flour, corn oil, cornflake, corn syrup, popcorn, rice corn and corn soap are some popular corn products. United States, China and Brazil are the top three maize producing countries in the world producing approximately 563 of the total 717 million metric tonnes per year (Ranum et al., 2014). In India, which is its sixth largest producing country, maize was introduced probably during the seventeenth century by the Portuguese and now stands up as the third cash crop after wheat and rice with about $24 \%$ of the maize produced used as human food, $16 \%$ as animal feed, 44 $\%$ as poultry feed while about $16 \%$ is utilized as an industrial raw material where most of the maize is processed through wet milling, producing starch as the major product, and oil, bran and gluten meal as byproducts (Sanjeev et al., 2014). About two million tonnes of maize is used in the starch industry in the country yielding about 70,000 tonnes of maize oil an- 
nually. This figure is expected to rise to 8 million tonnes of maize by 2050 in the starch industry, which can yield about 0.3 million tonnes of oil (Hegde, 2012). The quality of the maize kernel which is widely used in both human and animal feeding is considered to be mainly related to its protein and oil concentrations. A typical maize hybrid contains $8-15 \%$ protein (Reynolds et al., 2005), and most of these proteins consist of prolamins. The oil concentration of widely used maize hybrids varies between 3.5-5\% (Lambert, 2001, Laurie et al., 2004, Sanjeev et al., 2014); corn having oil content of more than $6 \%$ is regarded as high oil corn (Rajendran et al., 2012). Maize germ (embryo) is an oil-rich portion of the kernel containing $80-84 \%$ of total oil content followed by $12 \%$ in aleurone and $5 \%$ in endosperm (Rajendran et al., 2012). The quantity of germ in the kernel and oil in the germ is genetically controlled and varies widely (Becker, 2007). Among several corn related products, corn oil is an emerging one, increasingly becoming popular among edible oils owing to its unique health related benefits. Typical dent corn oil is tasteless and odorless containing $61.9 \%$ linoleic acid, $24.1 \%$ oleic acid, $11.0 \%$ palmitic acid, 2.0\% stearic acid, $0.7 \%$ linolenic acid, and traces of other fatty acids (White et al., 2007).

In the north western Indian Himalayan state Jammu and Kashmir, maize is second most important crop after rice and is a staple food of tribal population (Najeeb et al., 2012). The crop is generally grown under rainfed conditions on marginal lands $(1076 \mathrm{~mm}$ mean annual rainfall) particularly in hilly terrains, singly or intercropped with pulses such as common beans and green gram. Currently, the crop in the state is grown on an area of 309 thousand hectares with production of 461 thousand tonnes and productivity of 1495 kilograms/hectare against country level statistics of 9233 thousand hectares, 23673 thousand tonnes and 2564 kilograms/hectare respectively (GEOFIN, 2016). Even in presence of several high yielding varieties (Shalimar1, JMC 3), some landrace populations of maize are still popular in the farmers fields throughout the state owing to their better grain quality in terms of taste, better fodder quality, wider adaptability to local conditions, resistance to draught, cold, insects and pests, early maturity and low input requirement (Najeeb et al., 2012). The main aim of the present study was to evaluate protein content, oil content and fatty acid composition in maize genotypes collected from remote and hilly areas of the state. Assessment of extent of genetic variance existing in these quality traits in the local Zea mays germplasm may be helpful in developing nutritionally improved cultivars having industrial value as well.

\section{MATERIALS AND METHODS}

Plant material: Eleven genotypes of Zea mays L. collected from farmer fields during September/October
2016 in diverse hilly locations across the north western Indian Himalayan state of Jammu and Kashmir $\left(32^{\circ} 17^{\prime}\right.$ - $36^{\circ} 58^{\prime} \mathrm{N}$ latitude, $73^{\circ} 26^{\prime}$ - $80^{\circ} 30^{\prime} \mathrm{E}$ longitude) have been used in the present investigation (Table 1). At least seven cobs of each of these genotypes were randomly collected from the fields. Diversity was observed in cob length (cms), seed color, number of seed rows per cob and 100-seed weight (g) in these genotypes. After proper drying one major set of seeds was deposited in the National Gene Bank at ICAR-National Bureau of Plant Genetic Resources New Delhi for conservation and the other set was used for investigation of quality traits of protein content, oil content and fatty acid composition in the kernels. Seeds were selected from the central portion of the cobs as suggested by White and Weber (2003) to minimize the variance of oil content based on position on a cob.

Estimation of protein content: Crude protein was determined in $100 \mathrm{mg}$ of finely ground kernel samples by the micro Kjeldahl method as described by Pearson (1976). The percentage crude protein content in three independent samples in each genotype was calculated as $\% \mathrm{~N}$ multiplied by the coefficient 6.25 .

Estimation of oil content: Corn oil content was measured by TD NMR [Time-domain (TD) NMR bench top system (Bruker)]. The measurements were done in triplicate in each of the genotypes.

Determination of fatty acids: The oil was extracted from each sample using Soxhlet extractor following the method of AOAC (1990). $10 \mathrm{~g}$ sample was extracted with n-hexan at $70^{\circ} \mathrm{C}$ for 6 hours. Extracted oil was stored at $4^{\circ} \mathrm{C}$ to be used in fatty acid analyses by GCFID (The Gas Chromatography-Flame Ionization Detector) carried out on Perkin Elmer Auto system XL GC equipped with FID). The oils were converted to corresponding fatty acid methyl esters (FAMEs) as follows:

The fatty acids methyl esters (FAMEs) were prepared by refluxing the oil with methanol:toluene:sulfuric acid (20:10:1) for $30 \mathrm{~min}$ following the literature procedure (Hammond, 1993). GC analysis of FAMEs were carried out on a Agilent 4890D Gas Chromatogram equipped with a flame ionization detector (FID) using a polyethylene glycol coated FSCAP column (30 m x $0.25 \mathrm{~mm} \times 0.25 \mu \mathrm{m}$ film thickness; Supelcowax).Hydrogen was used as the carrier gas at column head pressure of 20 psi. Each sample $(0.2 \mu \mathrm{L})$ was injected into the injection port of the GC using a split ratio of 50:1. Temperature of the injector and detector was kept at $250^{\circ} \mathrm{C}$.Compound separation was achieved following a linear temperature program of $160^{\circ} \mathrm{C}(1 \mathrm{~min}), 160$ to $240^{\circ} \mathrm{C}\left(2^{\circ} \mathrm{C} / \mathrm{min}\right), 240^{\circ} \mathrm{C}(10$ $\mathrm{min})$, so the total run time was 51 minutes. Each sample was analyzed twice in GC. Peaks were identified by co-elution of standard methyl ester samples procured from Sigma-Aldrich in the same GC conditions. GC/MS utilized a Perkin Elmer auto system XL GC 
interfaced with a Turbo mass Quadrupole mass spectrometer based on the above oven temperature program. Injector, transfer line and source temperatures were $250{ }^{\circ} \mathrm{C}$; ionization energy $70 \mathrm{eV}$; helium at $10 \mathrm{psi}$ constant pressure; and mass scan range 40-500 amu. Characterization was achieved on the basis of retention time, elution order, calculated relative retention index using a homologous series of n-alkanes $\left(\mathrm{C}_{10}-\mathrm{C}_{32}\right.$ hydrocarbons, Polyscience Corp. Niles IL), mass spectral library search (NIST/EPA/NIH version 2.1 and Wiley registry of mass spectral data 7 th edition).

Statistical Analysis: Pearson correlation coefficients for the relationships between all these quality traits were calculated using Statistical Package for the Social Sciences (SPSS) Software, version 16.

\section{RESULTS AND DISCUSSION}

Significant differences were observed for protein and oil contents in Zea mays genotypes during the course of our present study (Table 2). The protein content ranged from $10.7 \%$ to $18.7 \%$ while oil content varied between $2.26 \%$ and $4.80 \%$. Highest and appreciable protein contents have been recorded in two genotypes IC-0617877 (18.7\%) and IC-0617880 (17.6\%). The saturated fatty acids of palmitic (C16:0), stearic (C18:0), arachidic (C20:0) and unsaturated fatty acids of oleic (C18:1), linoleic (C18:1) and elaidic (C18:1) are the six fatty acids which have been detected and measured during our present study in maize genotypes cultivated in north western Indian Himalayan state of Jammu and Kashmir (Table 3). Considerable variation has been recorded in these fatty acids; $13.8-33.4 \%$ for palmitic acid, 21.5-48.1\% for linoleic acid, 19.2-39\% for oleic acid, $0.2-2.4 \%$ for elaidic acid, $2.5-8.5 \%$ for stearic acid and $0.1-6.6 \%$ for arachidic acid. Higher oleic acid content has been found in all genotypes excepting IC-0617881. Interestingly, highest oil (4.80\%), palmitic acid (33.4\%), stearic acid $(8.5 \%)$ and arachidic acid $(6.6 \%)$ contents have been recorded in this remarkably cold tolerant genotype with reddish yellow seeds containing moderate protein content of $13.8 \%$.

High yield is one of the main breeding goals in maize and substantial work has been done on improvement of yield as well as quality traits (Egesel et al., 2013). The typical maize kernel, on dry weight basis is composed of $61-78 \%$ of starch, $6-12 \%$ of proteins, $3.1-5.7 \%$ of oil, $1.0-3.0 \%$ of sugar and $1.1-3.9 \%$ of ash (Watson, 2003). In five different and recent studies on maize genotypes across the world protein content has been found to vary between $9.4-13 \%, 11.02-13.02 \%, 11.02-$ $15.31 \%, 8.05-11.43 \%$ and $6.27-8.06 \%$, while oil content has been found to vary between $3.32-4.70 \%, 2.56-$ $5.57 \%, 4.39-9.71 \%, 3.80-5.02 \%$ and $2.7-5.2 \%$ respectively (Egesel et al., 2011, Aliu et al., 2012, Sanjeev et al., 2014, Scrob et al., 2014, Chibuike et al., 2015). In India, higher contents of oil $(9.71 \%)$ and protein $(15.31 \%)$ have been observed in sweet corn samples and attributed to shriveled grain texture because of an

Table 1. Zea mays genotypes and their collection sites in the north western Indian Himalayan state of Jammu \& Kashmir used in the present study.

\begin{tabular}{llllll}
\hline S. No. & Accession number & Place of collection & District & Latitude & Longitude \\
\hline 1 & IC-0617874 & Bhalra Bhaderwah & Doda & $33^{\circ} 01^{\prime}$ & $75^{\circ} 41^{\prime}$ \\
2 & IC-0617875 & Bidha & Kishtwar & $33^{\circ} 19^{\prime}$ & $75^{\circ} 55^{\prime}$ \\
3 & IC-0617876 & Gool Gulabgarh & Ramban & $33^{\circ} 15^{\prime}$ & $75^{\circ} 00^{\prime}$ \\
4 & IC-0617877 & Balot Bhaderwah & Doda & $33^{\circ} 01^{\prime}$ & $75^{\circ} 42^{\prime}$ \\
5 & IC-0617878 & Bidha & Kishtwar & $33^{\circ} 19^{\prime}$ & $75^{\circ} 55^{\prime}$ \\
6 & IC-0617879 & Batote & Ramban & $33^{\circ} 07^{\prime}$ & $75^{\circ} 19^{\prime}$ \\
7 & IC-0617880 & Ghowari Ghatha Bhaderwah & Doda & $32^{\circ} 59^{\prime}$ & $75^{\circ} 42^{\prime}$ \\
8 & IC-0617881 & Gulistan Tral & Pulwama & $34^{\circ} 03^{\prime}$ & $75^{\circ} 04^{\prime}$ \\
9 & IC-0617882 & Gutroo Tral & Pulwama & $34^{\circ} 02^{\prime}$ & $75^{\circ} 05^{\prime}$ \\
10 & IC-0617883 & Karnah & Kupwara & $33^{\circ} 09^{\prime}$ & $76^{\circ} 15^{\prime}$ \\
11 & IC-0617884 & Kralpora & Kupwara & $34^{\circ} 29^{\prime}$ & $74^{\circ} 07^{\prime}$ \\
\hline
\end{tabular}

Table 2. Protein and oil contents of Zea mays genotypes collected from north western Indian Himalayan state of Jammu and Kashmir.

\begin{tabular}{llll}
\hline S No. & Genotype & Protein content (\%) & Oil content (\%) \\
\hline 1 & IC-0617874 & $15.6 \pm 0.5$ & $2.26 \pm 0.07$ \\
2 & IC-0617875 & $15.2 \pm 0.3$ & $4.02 \pm 0.03$ \\
3 & IC-0617876 & $15.7 \pm 0.7$ & $3.48 \pm 0.19$ \\
4 & IC-0617877 & $18.7 \pm 0.4$ & $4.40 \pm 0.09$ \\
5 & IC-0617878 & $13.6 \pm 0.8$ & $3.47 \pm 0.07$ \\
6 & IC-0617879 & $12.7 \pm 0.7$ & $3.57 \pm 0.16$ \\
7 & IC-0617880 & $17.6 \pm 0.4$ & $4.10 \pm 0.02$ \\
8 & IC-0617881 & $13.8 \pm 0.1$ & $4.80 \pm 0.09$ \\
9 & IC-0617882 & $12.2 \pm 0.7$ & $4.58 \pm 0.19$ \\
10 & IC-0617883 & $14.1 \pm 0.5$ & $3.44 \pm 0.04$ \\
11 & IC-0617884 & $10.7 \pm 0.6$ & $3.37 \pm 0.03$ \\
\end{tabular}


Table 3. Fatty acid composition (\%) of Zea mays genotypes collected from north western Indian Himalayan state of Jammu and Kashmir.

\begin{tabular}{llllllll}
\hline S. No. & Genotype & Palmitic acid & Linoleic acid & Oleic acid & Elaidic acid & Stearic acid & Arachidic acid \\
\hline 1 & IC-0617874 & 13.8 & 48.1 & 33.6 & 0.9 & 2.8 & 0.3 \\
2 & IC-0617875 & 26.3 & 22.2 & 37.4 & 2.4 & 6.5 & 1.4 \\
3 & IC-0617876 & 14.6 & 42.6 & 37.3 & 0.7 & 4.0 & 0.2 \\
4 & IC-0617877 & 14.7 & 44.8 & 34.7 & 0.9 & 3.8 & 0.2 \\
5 & IC-0617878 & 16.1 & 41.4 & 38.9 & 0.2 & 3.2 & 0.1 \\
6 & IC-0617879 & 14.5 & 44.6 & 36.5 & 0.6 & 2.5 & 0.2 \\
7 & IC-0617880 & 14.9 & 41.2 & 39.0 & 0.8 & 2.9 & 0.2 \\
8 & IC-0617881 & 33.4 & 21.5 & 19.2 & 1.1 & 8.5 & 6.6 \\
9 & IC-0617882 & 23.1 & 28.1 & 36.1 & 1.4 & 4.6 & 5.7 \\
10 & IC-0617883 & 15.3 & 42.0 & 37.1 & 0.9 & 2.9 & 0.2 \\
11 & IC-0617884 & 14.7 & 43.5 & 36.6 & 0.7 & 2.8 & 0.2 \\
\hline
\end{tabular}

Table 4. Pearson correlation coefficients of fatty acid, protein and oil contents of Zea mays genotypes.

\begin{tabular}{lllllllll}
\hline & $\begin{array}{l}\text { Palmitic } \\
\text { acid }\end{array}$ & $\begin{array}{l}\text { Linoleic } \\
\text { acid }\end{array}$ & $\begin{array}{l}\text { Oleic } \\
\text { acid }\end{array}$ & $\begin{array}{l}\text { Elaidic } \\
\text { acid }\end{array}$ & $\begin{array}{l}\text { Stearic } \\
\text { acid }\end{array}$ & $\begin{array}{l}\text { Arachidic } \\
\text { acid }\end{array}$ & $\begin{array}{l}\text { Protein con- } \\
\text { tent (\%) }\end{array}$ & $\begin{array}{l}\text { Oil con- } \\
\text { tent (\%) }\end{array}$ \\
\hline Palmitic acid & 1.000 & & & & & & & \\
Linoleic acid & $-.958^{* *}$ & 1.000 & & & & & & \\
Oleic acid & $-.718^{*}$ & .495 & 1.000 & & & & & \\
Elaidic acid & $.604^{*}$ & $-.726^{*}$ & -.111 & 1.000 & & & \\
Stearic acid & $.960^{* *}$ & $-.903^{* *}$ & $-.743^{* *}$ & .596 & 1.000 & & \\
Arachidic acid & $.860^{* *}$ & $-.797^{* *}$ & $-.716^{*}$ & .377 & $.770^{* *}$ & 1.000 & & 1.000 \\
Protein content (\%) & -.159 & .161 & .063 & .093 & .018 & -.270 & 1.000 & .103 \\
Oil content (\%) & $.651^{*}$ & $-.683^{*}$ & -.383 & .340 & $.635^{*}$ & $.660^{*}$ & .000 \\
\hline
\end{tabular}

** Correlation is significant at the 0.01 level (2-tailed), * Correlation is significant at the 0.05 level (2-tailed)

increased embryo to kernel ratio (Sanjeev et al., 2014) which is in consonance with our study. The higher protein content in some of the genotypes especially IC $-0617877(18.7 \%)$ and IC-0617880 (17.6\%) is quite appreciable and thus may serve as promising donors for this trait in maize breeding programmes. Maize kernel quality is considered to be mainly related to protein and oil concentration. Although higher oil content is a desirable trait in corn as it provides higher energy to the consumers, the oil quality in terms of fatty acid composition plays a more important role in human nutrition. Owing to its numerous health benefits, non-traditional corn oil is gaining importance in the international market; development of high oil corn with desired composition is now receiving increasing attention in India as the country is the third largest importer and consumer of edible oils (Ambika et al., 2012). Development of superior high oil inbred lines for commercial use is one of the major goals of today's maize improvement programmes. High oil maize with ideal fatty acid composition will offer maize growers higher profits through the Indian markets. Fatty acid contents of 9.2-12.7\% (palmitic acid), 1.46$2.14 \%$ (stearic acid), 23.3-35.4\% (oleic acid), 50.8$62.4 \%$ (linoleic acid) and $0.42-0.66 \%$ (arachidic acid) have been reported in normal maize oil (Egesel et al., 2011). In India, Sanjeev et al. (2014) have recorded $12.61-16.22 \%$ palmitic acid, 2.63-6.04\% stearic acid, $33.54-46.61 \%$ oleic acid and 33.00-44.65\% linoleic acid contents in the oil obtained from several normal and specialty maize genotypes. Thus, our findings on protein and oil content as well as fatty acid composition in the present study essentially corroborate these reports. However, in the genotypes IC-0617881 and IC -0617882 high arachidic acid content of $6.6 \%$ and $5.7 \%$ respectively has been found; much higher than reported in maize earlier. The average arachidic acid content of peanuts is $2.3 \%$ which is considered as richest source of this fatty acid. Hence these maize genotypes may serve useful donor parents for breeding genotypes rich in arachidic acid. Further, barring a single genotype IC-0617881, higher oleic acid content has been found in all other genotypes which is a useful trait. Oleic acid which has some advantages over the other fatty acids in terms of cooking and health is normally found in corn oil at a level of about $25 \%$, and genotypes with higher levels of this fatty acid are economically more valuable (Mikkilineni and Rocheford, 2003). The high content of unsaturated fatty acid in maize oil is the main factor in its high quality (Ozcan, 2009).

Correlation coefficients between various traits studied have been given in Table 4. No correlation has been found between crude protein content and any of the fatty acids or overall oil content. However, oil content showed a significant positive correlation with palmitic, linoleic, stearic and arachidic acid contents. Regarding correlations among different fatty acids, it has been found that palmitic acid showed significant negative correlation with oleic acid $(\mathrm{r}=-0.718)$ and linoleic acid $(r=-958)$ but a positive correlation with elaidic, stearic and arachidic acids. Similarly, linoleic acid has been 
found to be negatively correlated with elaidic, stearic and arachidic acids, while oleic acid showed a negative correlation with stearic and arachidic acids. On the other hand stearic acid has been found to be positive correlated with arachidic acid content. Considering the correlations among various fatty acids, it appears that all the fatty acids seldom contribute to that total oil production and some of them serve as precursors for compounds other than oil. Our results are thus in contrast with those of Ignjatovic-Micic et al. (2015) who have found significant positive correlations between maize protein and oil contents and non-significant correlation between oil content and principal fatty acids. Moreover, their study has revealed a positive correlation between palmitic and oleic acids.

\section{Conclusion}

In the present investigation, although only 11 local maize genotypes were studied but results have indicated a considerable variation existing among the genotypes not only in crude protein content but also in oil content and fatty acid composition. The genotypes identified for higher contents of protein: IC-0617877 (18.7\%) and IC-0617880 (17.6\%), palmitic acid: IC0617881 (33.4\%) and IC-0617875 (26.3\%), stearic acid: IC-0617881 (8.5\%) and IC-0617875 (6.5\%) and arachidic acid: IC-0617881 (6.6\%) and IC-0617882 $(5.7 \%)$ may serve as promising donors for improvement of these traits in maize breeding programmes. Therefore, the local maize germplasm needs to be characterized for such quality traits on large scale for corn improvement strategies which would open up new opportunities for food and industrial end uses of this crop, ensuring nutritional and livelihood security of the tribal people in the region.

\section{ACKNOWLEDGEMENTS}

The authors wish to thank the Director, ICAR-NBPGR and the Head, Division of Exploration and Germplasm Collection, ICAR-NBPGR, New Delhi for their guidance, facilities and help.

\section{REFERENCES}

Aliu, S., Rusinovic, I., Fetahu, S. and Simeonovska, E. (2012). Genetic diversity and correlation estimates for grain yield and quality traits in Kosovo local maize (Zea mays L.) populations. Acta agriculturae Slovenica, 99: 121-28.

Ambika, R. R., Singh, N., Mahajan, V., Chaudhary, D. P., Sapna, S. and Kumar, R. (2012). Corn Oil: An emerg-ing industrial product. Technical Bulletin, No. 8, pp. 36, Directorate of Maize Research, New Delhi.

AOAC (1990). Association of Official Analytical Chemists. Methods of the association of official analytical chemists. Method No. 920.85. $15^{\text {th }}$ ed. V. II. Arlington.

Becker, R. (2007). Fatty acids in food cereal grains and grain products. Fatty Acids in Foods and their Health Implications, pp. 303-316.
Chibuike, C. S., Okporie, E. O., Ekwu, L. G., Onyishi, G. C. and Nwogbaga, A. C. (2015). Maize genotypes collection and characterization from local Government areas in Ebonyi state, Nigeria. J. Plant Breed. Genet., 3(1):17-23.

Doebley, J. F. (2004). The genetics of maize evolution. Ann Rev Genet., 38: 37-59.

Egesel, C. O., Kahriman, F. and Corbacioglu, N. (2013). The effects of generation and parents on endosperm protein ratio and change of protein fractions in maize. Anadolu Journal of Agricultural Sciences, 28(3): 150-156.

Egesel, O. C., Kahriman, F. and Gul, M. (2011). Discrimination of maize inbreds for kernel quality traits and fatty acid composition by a multivariate technique. Acta scientarium Agronomy, 33: 613-620.

Enujeke, E. C. (2013). Response of Grain Weight of Maize to Variety, Organic Manure and Inorganic Fertilizer in Asaba Area of Delta State. Asian J. Agric. Rural Dev., 3 (5): 234-248.

GEOFIN (2016). GEOFIN Maize Special Report. Geofin Comtrade Ltd. Geofin Research Desk, Kochi-682 024, Kerala.

Hammond, E. G. (1993). Organization of rapid analysis of lipids in many individual plants. pp. 321-330. In: Linskins, H. F. and Jackson, J. F. (Eds.), Modern Methods of Plant Analysis. New Series. Vol. 12. Springer-Verlag, Berlin.

Hegde, D. M. (2012). Carrying capacity of Indian agriculture: oilseeds. Curr Sci., 102: 867- 873.

Ignjatovic-Micic, D., Vancetovic, J., Trabovic, D., Dumanovic, Z., Kostadinovic, M., Bozinovic, S. (2015). Grain nutrient composition of maize (Zea mays L.) drought-tolerant populations. Journal of Agricultural and Food Chemistry, 63(4): 1251-1260.

Lambert, R. J. (2001). High-oil corn hybrids. In: Speciality corns. Hallauer A.R. (Ed.), $2^{\text {nd }}$ edition. CRC Press, Boca Raton, FL., USA. pp. 131-154.

Laurie, C. C., Chasalow, S. D., Ledeaux, J. R., Mc Carrolla, R., Bush, D., Hange, B., Lai, C., Clark, D., Rocheford, T. R. and Dudly, J. W. (2004). The genetic architecture of response to long-term artificial selection for oil concentration in the maize kernel. Genetics, 168: 21412155.

Matsuoka, Y., Vigouroux, Y., Goodman, M. M., Sanchez, G. J., Buckler, E. and Doebley, J. (2002). A single domestication for maize shown by multilocus microsatellite genotyping. Proc Natl Acad Sci., 99: 6080- 6084.

Mikkilineni, V. and Rocheford, T. R. (2003). Sequence variation and genomic organization of fatty acid desaturase2 (fad2) and fatty acid desaturase-6 (fad6) cDNAs in maize. Theorotical Applied Genetetics, 106: 1326-1332.

Najeeb, S., Rather, A. G., Zarger, M. A., Ahangar, M. A., Sheikh, F. A., Parray, G. A., Bhat, Z. A., Sofi, P. A., Kashap, S. C., Ishfaq, A., Dar, Z. A., Mehfoza, H. and Bardi, Z. A. (2012). Maize landraces of Kashmir: present status and future prospects. Maize Genetics Cooperation Newsletter, 86: 1-11.

Ortega, P., Martínez, A. and Sánchez, G. (2000). Recursos fitogenéticos autóctonos. In Recursos Fitogenéticos de México para la Alimentación y la Agricultura. Ramírez V., P., R.

Ozcan, S. (2009). Corn, indispensable crop of the modern world: Contribution of genetically modified (transgenic) corn on agricultural production. Turkish Journal of Sci- 
entific Reviews, 2(2): 1-34.

Pearson, D. (1976). The Chemical Analysis of Foods. $7^{\text {th }}$ ed., Churchill Livingstone, Edinburgh.

Ranum, P., Pena-Rosas, J. P., Garcia-Casal, M. N. (2014). Global maize production, utilization and consumption. Annals of the New York Academy of Sciences, 1312: 105- 112 .

Rajendran, R.A., Singh, N., Mahajan, V., Chaudhary, D. P., Sapna, S. and Kumar, R. S. (2012). Corn oil: an emerging industrial product. Directorate of maize research, New Delhi. Technical Bulletin, 8: 36.

Reynolds, T. L., Nemeth, M. A., Glenn, K. C., Ridley, W. P., Astwood, J. D. (2005). Natural variability of metabolites in maize grain: differences due to genetic background. Journal of Agricultural and Food Chemistry, 53: 10061 $-10067$.

Sanjeev, P., Chaudhary, D. P., Sreevastava, P., Saha, S., Rajenderan, A., Sekhar, J. C., Chikkappa, G. K. (2014). Comparison of Fatty Acid Profile of Specialty Maize to Normal Maize. J Am Oil Chem Soc., DOI 10.1007/ s11746-014-2429-y.
Scrob, S., Muste, S., Has, J., Muresan, C., Socaci, S. and Fărcas, A. (2014). The Biochemical Composition and Correlation Estimates for Grain Quality in Maize. Journal of Agroalimentary Processes and Technologies, 20 (2): 150-155

Vigouroux, Y., Glaubitz, J. C., Matsuoka, Y., Goodman, M. M., Sanchez, G. J. and Doebley, J. F. (2008). Population structure and genetic diversity of New World maize races assessed by DNA microsatellites. American J Bot., 95: 1240-1253.

Watson, S. A. (2003). Description, development, structure and composition of the corn kernel, pp. 69-106. In: Corn: Chemistry and Technology. White, P. J. and Johnson, L. A. (Eds.), Am Assn Cereal Chemists Inc St. Paul, MN.

White, P. J. and Weber, E. J. (2003). Lipids of the kernel, pp. 355-405. In: Corn: Chemistry and Technol-ogy. White, P. J. and Johnson, L. A. (Eds.) Am Assn Cereal Chemists Inc St. Paul, MN

White, P. J., Pollak, L. M. and Duvick, S. (2007). Improving the fatty acid composition of corn oil by using germplasm introgression. Lipid Technology, 19(2): 35-38. 